\title{
Effect of short glass fiber on shear capacity for shallow wide reinforced concrete beams
}

\author{
Mohamed S. Moawadid
}

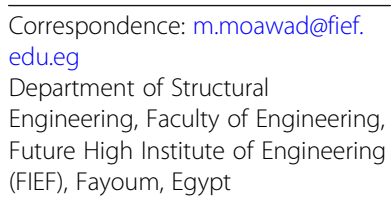

\begin{abstract}
Shallow wide reinforced concrete beams are used in modern buildings especially in residential building structures. According to current Egyptian Code Practice 203-2018; the characteristic of a shallow wide concrete beam is that the cross-section width (b) over the effective depth (d) ratio is greater than two and the beam depth is less than $250 \mathrm{~mm}$. Without any shear reinforcing contribution, the applied shear stresses in shallow wide beams must be less than the concrete shear strength. And only concrete provides shear strength. An experimental program was conducted to investigate the contribution of short glass fiber polymer reinforcement to shear strength in shallow wide beams under shear stress. The short glass fiber polymer reinforcement ratio was the main parameter in this study. And also, the contribution of web shear stirrups reinforces against shear stresses. The experimental program consisted of five simply supported reinforced shallow wide concrete beams. Test results show that the use of short glass fiber reinforced polymer has a great effect on shear strength capacity, mode of failure, and ductility of shallow wide concrete beams.
\end{abstract}

Keywords: Short glass fiber, Polymer, Shear strength, Hidden beams, Ductility

\section{Introduction}

Short glass fiber reinforced polymers have been widely used in a variety of applications, including construction industries, pipes, and storage tanks, due to their mechanical properties conjugated to ease and low cost of fabrication, as well as design flexibility [1]. Glass fiber reinforced polymer (GFRP) is commonly used as a retrofitting material these days due to their good properties [2]. Glass fiber is has an excellent property like high tensile strength, flexibility, stiffness, and resistance to chemical harm; in addition, the glass fiber reinforced polymer materials are lightweight [3]. Adding glass fibers to concrete mixes increases its durability and sturdiness and short glass fiber can be used anywhere [4].

Wide shallow concrete beams in concrete buildings are mainly constructed as hidden beams because they have the same depth as the supported floor. Shallow wide reinforced

(c) The Author(s). 2021 Open Access This article is licensed under a Creative Commons Attribution 4.0 International License, which permits use, sharing, adaptation, distribution and reproduction in any medium or format, as long as you give appropriate credit to the original author(s) and the source, provide a link to the Creative Commons licence, and indicate if changes were made. The images or other third party material in this article are included in the article's Creative Commons licence, unless indicated otherwise in a credit line to the material. If material is not included in the article's Creative Commons licence and your intended use is not permitted by statutory regulation or exceeds the permitted use, you will need to obtain permission directly from the copyright holder. To view a copy of this licence, visit http://creativecommons.org/licenses/by/4.0/. The Creative Commons Public Domain Dedication waiver (http://creativecommons.org/publicdomain/zero/1.0/) applies to the data made available in this article, unless otherwise stated in a credit line to the data. 
concrete beams can carry direct loads or act as primary transfer elements. However, the shear stresses failure in the shallow wide reinforced concrete beams structures is highly brittle when compared with the flexural failure [5].

Egyptian code practice 203-2018 was called beams which have a total depth not greater than $250 \mathrm{~mm}, 2.5$ times thickness of the flange, or half of the width of the web, whichever is greater shallow wide concrete beams (hidden beams). And the shear stresses must be less than the concrete shear strength with no consideration of the contribution of shear reinforcement [6]. As a consequence, large cross-sectional area of concrete has to be provided to meet one-way shear demands. While the code [5] totally ignores the contribution of web reinforcement to shear strength, in practice, a minimum web reinforcement is provided. Due to the previous code provisions [5] is a very conservative and uneconomic shear design of shallow wide beams.

The target of the present study was to investigate the effectiveness of shear reinforcement, by using a minimum of web steel stirrup reinforcement only, or by using both short glass fiber reinforced polymer with a minimum web steel stirrup reinforcement as per ECP. 203-2018 requirements, to increase shear strength capacity of shallow wide reinforced concrete beams.

The contribution of web shear reinforcement to shear strength was investigated by $\mathrm{E}$. lofty, and H.A. mohamdien [7], and it was concluded that the use of vertical stirrups in shallow wide beams increases shear strength capacity and ductility. The importance of web shear reinforcement in the form of vertical stirrups in increasing the shear strength capacity of a shallow wide reinforced concrete beam cannot be ignored.

The shear strength of tested concrete beams reinforced by short glass fiber was significantly increased as a percentage of fiber increased and became finer. The failure mode becomes more ductile also [4].

Min Sook Kim, Joowon Kang, and Young Hak Lee [8] tested a total of six concrete shallow wide reinforced concrete beams were reinforced with glass fiber reinforced polymer GFRP plates as shear reinforcement against shear performance and concluded that the shear behavior and its performance increases as the spacing of the transverse shear reinforcement decreases.

M.S. Kim et al. [9] reported that the shear capacity decreased as the transverse reinforcement spacing increased, and there was no significant effect of the number of legs on the shear strength. Mohamed M. Hanafy, Hatem M. Mohamed, and Nabil A.B. Yehia [10] showed that the significance of the web reinforcement in improving the shear capacity by increasing the ductility of the shallow wide beams. Emad E.E. et al. carried out an experimental study to investigate the performance of shallow wide beam against shear stresses and

Table 1 Concrete mix design

\begin{tabular}{llll}
\hline Material & Specific gravity & Weight $(\mathbf{k g})$ & Volume $\left(\mathbf{m}^{\mathbf{3}}\right)$ \\
\hline Cement & 3.15 & 330 & 0.104 \\
Sand & 2.61 & 790 & 0.302 \\
Aggregate size $20 \mathrm{~mm}$ & 2.67 & 540 & 0.202 \\
Aggregate size $5-14 \mathrm{~mm}$ & 2.63 & 540 & 0.205 \\
Free water & 1 & 170 & 0.17 \\
Air voids \% & ----- & $---{ }^{--}$ & 0.02 \\
W/c & 0.515 & & \\
\hline
\end{tabular}




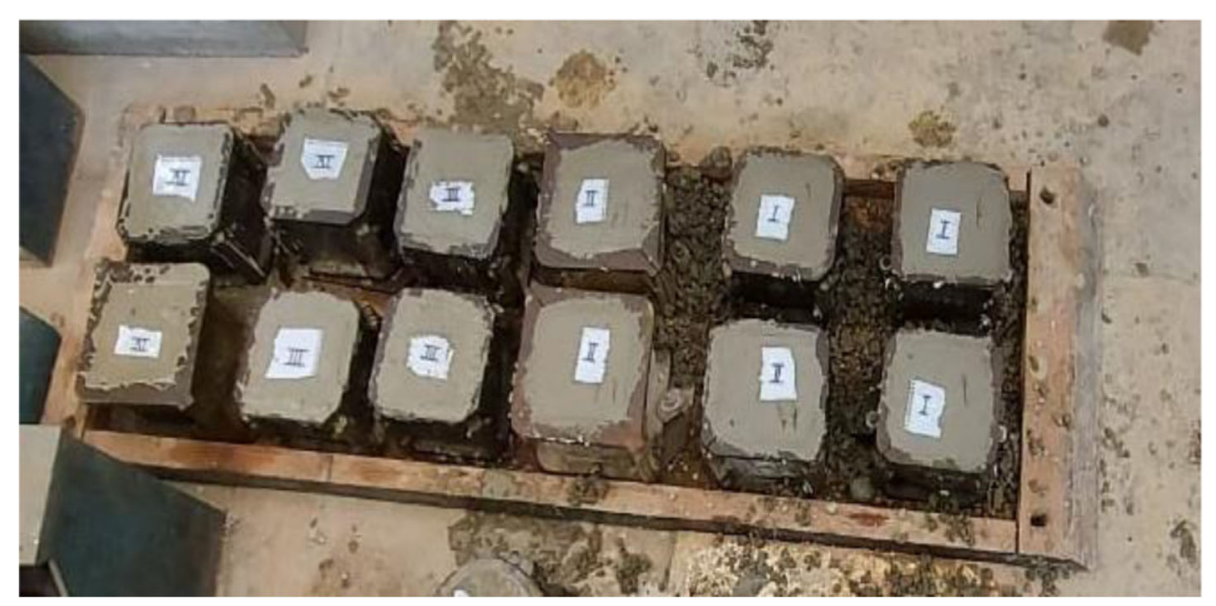

Fig. 1 Concrete cubes $(150 \times 150 \times 150 \mathrm{~mm})$

concluded that the ratio between width to effective depth ratios (b/d) seems to significantly influence the mechanism of failure and the shear capacity. Increasing steel stirrup reinforcement leads to a small enhancement in the shear capacity of a wide concrete beam [11].

\section{Methods}

\section{Aim of the study}

This experimental program aimed to study the effect and of using short glass fiber reinforced polymer randomly distributed in shallow wide reinforced concrete beams against shear strength by using a different fiber content.

The fundamental object of this research paper is to study the contribution of the short glass fiber polymer as a reinforcement with a minimum of steel stirrups web shear reinforcement as per ECP.203-2018 in shear strength for a shallow wide reinforced concrete beam.

Table 2 Concrete compressive strength

\begin{tabular}{|c|c|c|c|c|c|c|c|c|c|}
\hline \multirow[t]{2}{*}{ Concrete type } & \multirow{2}{*}{\multicolumn{2}{|c|}{$\begin{array}{l}\text { Sample } \\
\text { (ID) }\end{array}$}} & \multirow{2}{*}{$\begin{array}{l}\text { Weight } \\
\text { (kg) }\end{array}$} & \multicolumn{3}{|c|}{ Dimension } & \multirow{2}{*}{$\begin{array}{l}\text { Failure } \\
\text { load (KN) }\end{array}$} & \multirow{2}{*}{$\begin{array}{l}\text { Fcu } \\
\left(\mathrm{N} / \mathrm{mm}^{2}\right)\end{array}$} & \multirow{2}{*}{$\begin{array}{l}\text { Average Fcu } \\
\left(\mathrm{N} / \mathrm{mm}^{2}\right)\end{array}$} \\
\hline & & & & $\begin{array}{l}\text { Length } \\
(\mathrm{mm})\end{array}$ & $\begin{array}{l}\text { Width } \\
(\mathrm{mm})\end{array}$ & $\begin{array}{l}\text { Height } \\
(\mathrm{mm})\end{array}$ & & & \\
\hline \multirow[t]{3}{*}{ Concrete without GFRP } & G1 & I & 8.65 & 150 & 151 & 150 & 585 & 26.0 & 25.5 \\
\hline & & $\|$ & 8.85 & 150 & 150 & 150 & 573.7 & 25.5 & \\
\hline & & III & 8.55 & 151 & 149 & 150 & 562.5 & 25 & \\
\hline \multirow[t]{3}{*}{ Concrete with $(0.50 \%)$ GFRP } & G2 & I & 8.95 & 150 & 150 & 151 & 607.5 & 27 & 26 \\
\hline & & $\|$ & 8.96 & 150 & 149 & 150 & 585 & 26 & \\
\hline & & III & 9.15 & 151 & 149 & 150 & 562.5 & 25 & \\
\hline \multirow[t]{3}{*}{ Concrete with (1.00\%) GFRP } & G3 & I & 9.35 & 150 & 149 & 150 & 585 & 26 & 25.7 \\
\hline & & $\|$ & 9.92 & 150 & 151 & 150 & 585 & 26 & \\
\hline & & III & 9.24 & 149 & 150 & 151 & 562.5 & 25 & \\
\hline \multirow[t]{3}{*}{ Concrete with (1.50\%) GFRP } & G4 & I & 9.50 & 150 & 150 & 150 & 607.5 & 27 & 26.7 \\
\hline & & $\|$ & 8.92 & 150 & 150 & 151 & 585.0 & 26 & \\
\hline & & III & 9.80 & 151 & 150 & 150 & 607.5 & 27 & \\
\hline
\end{tabular}


Table 3 Splitting concrete strength

\begin{tabular}{|c|c|c|c|c|c|c|c|c|c|}
\hline \multirow[t]{2}{*}{ Concrete type } & \multirow{2}{*}{\multicolumn{2}{|c|}{$\begin{array}{l}\text { Sample } \\
\text { (ID) }\end{array}$}} & \multirow{2}{*}{$\begin{array}{l}\text { Weight } \\
\text { (kg) }\end{array}$} & \multicolumn{2}{|l|}{ Dimension } & \multirow{2}{*}{$\begin{array}{l}\text { Failure } \\
\text { load } \\
\text { (KN) }\end{array}$} & \multirow{2}{*}{$\begin{array}{l}\mathrm{F}_{\mathrm{ct}} \\
\left(\mathrm{N} / \mathrm{mm}^{2}\right)\end{array}$} & \multirow{2}{*}{$\begin{array}{l}\text { Average } F_{c t} \\
\left(\mathrm{~N} / \mathrm{mm}^{2}\right)\end{array}$} & \multirow[b]{2}{*}{$\begin{array}{l}\text { Difference } \\
\text { percentage } \\
\text { of concrete } \\
\text { splitting } \\
\text { strength } \\
\text { due to short } \\
\text { glass fiber }\end{array}$} \\
\hline & & & & $\begin{array}{l}\text { Diameter } \\
(\mathrm{mm})\end{array}$ & $\begin{array}{l}\text { Height } \\
(\mathrm{mm})\end{array}$ & & & & \\
\hline \multirow{2}{*}{$\begin{array}{l}\text { Concrete without } \\
\text { GFRP }\end{array}$} & \multirow[t]{2}{*}{ G1 } & 1 & 13.172 & 150.5 & 300 & 120 & 1.71 & 1.89 & ----- \\
\hline & & $\|$ & 13.182 & 150 & 305 & 150 & 2.08 & & \\
\hline \multirow{2}{*}{$\begin{array}{l}\text { Concrete with } \\
(0.50 \%) \text { GFRP }\end{array}$} & \multirow[t]{2}{*}{ G2 } & I & 13.00 & 150 & 303 & 289 & 4.04 & 4.08 & $53.7 \%$ \\
\hline & & $\|$ & 13.05 & 150 & 302 & 294 & 4.13 & & \\
\hline \multirow{2}{*}{$\begin{array}{l}\text { Concrete with } \\
(1.00 \%) \text { GFRP }\end{array}$} & \multirow[t]{2}{*}{ G3 } & I & 12. 95 & 149.5 & 300 & 322 & 4.57 & 4.58 & $58.73 \%$ \\
\hline & & $\|$ & 12.93 & 149.5 & 304 & 327 & 4.58 & & \\
\hline \multirow{2}{*}{$\begin{array}{l}\text { Concrete with } \\
(1.50 \%) \text { GFRP }\end{array}$} & \multirow[t]{2}{*}{ G4 } & I & 12.80 & 149.5 & 301 & 308 & 4.35 & 4.30 & $56.05 \%$ \\
\hline & & ॥ & 12.87 & 150 & 300 & 312 & 4.24 & & \\
\hline
\end{tabular}

\section{Experimental program}

To investigate the effect of the experimental parameters on the shear stress behavior of a shallow wide reinforced concrete beam, an experimental program consisted of five reinforced concrete beams divided into three groups based on shear web reinforcement contribution and short glass fiber reinforcement volume to resist shear stresses with 25 MPa concrete compressive strength. Shallow wide reinforced concrete beam was loaded up to failure.

\section{Materials and mix design}

Concrete Trial mixes were conducted to reach the target concrete compressive strength of $25 \mathrm{MPa}$ after 28 days. Concrete mix proportion design by weight of the quantities of materials was listed in Table 1 to control the quality of concrete mix, three cubes were randomly poured from the same batches of the beams and then testes as shown in Fig. 1. And Table 2 is summarizing the cubes' data and the corresponding failure load and characteristic compressive strength at 28 days. Table 3 showed that the test results of concrete tensile strength due to splitting strength at 28 days.

Table 4 Mechanical properties of steel reinforcement bars

\begin{tabular}{lllllll}
\hline Bar size & $\begin{array}{l}\text { Unit weight } \\
\left(\mathbf{k g} / \mathbf{m}^{\prime}\right)\end{array}$ & $\begin{array}{l}\text { Yield strength, } \\
\mathbf{R}_{\mathbf{e H}}\left(\mathbf{N} / \mathbf{m m}^{\mathbf{2}}\right)\end{array}$ & $\begin{array}{l}\text { Tensile strength, } \\
\mathbf{R m}\left(\mathbf{N} / \mathbf{m}^{\mathbf{2}}\right)\end{array}$ & $\mathbf{R m} / \mathbf{R}_{\mathrm{eH}}$ & Elongation \% & Bend test \\
\hline $8 \mathrm{~mm}$ & 0.402 & 275 & 426 & 1.55 & 18.5 & pass \\
& 0.401 & 264 & 402 & 1.52 & 17.8 & pass \\
& 0.395 & 278 & 431 & 1.55 & 16.8 & pass \\
$12 \mathrm{~mm}$ & 0.901 & 380 & 560 & 1.47 & 12.5 & pass \\
& 0.895 & 375 & 556 & 1.48 & 13.4 & pass \\
& 0.891 & 370 & 536 & 1.44 & 13.9 & pass \\
\hline
\end{tabular}




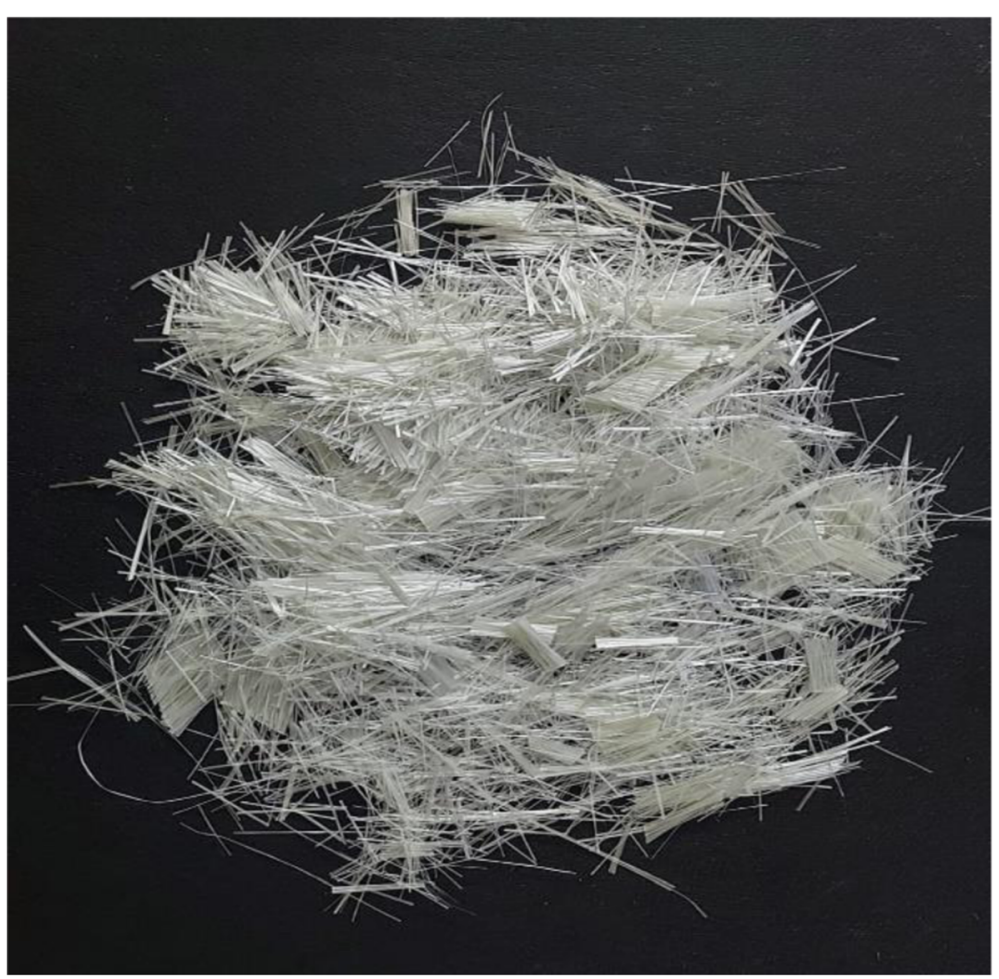

Fig. 2 Short glass fiber reinforced polymer

Reinforcing steel bars High yielding strength deformed bars of $12 \mathrm{~mm}$ are used to resist flexural stresses and $8 \mathrm{~mm}$ diameter normal mild steel is used as a compression steel reinforcement and stirrups for finding a tensile strength three specimens of each bar diameter were tested to find and calculate the mechanical properties of steel bars reinforcement. mechanical properties of steel bars reinforcement are listed in Table 4 .

Short glass fiber reinforced polymer The introduction of non-ferrous reinforcement, either in the form of a randomly distributed monofilament glass fiber chopped form type E of glass is shown in Fig. 2. The fibers are coated with silane based to sizing to improve initial dispersion and bond. The short glass fibers are extremely fine, single filaments, measuring 13 microns in diameter, cut to an average length of $24 \mathrm{~mm}$, in

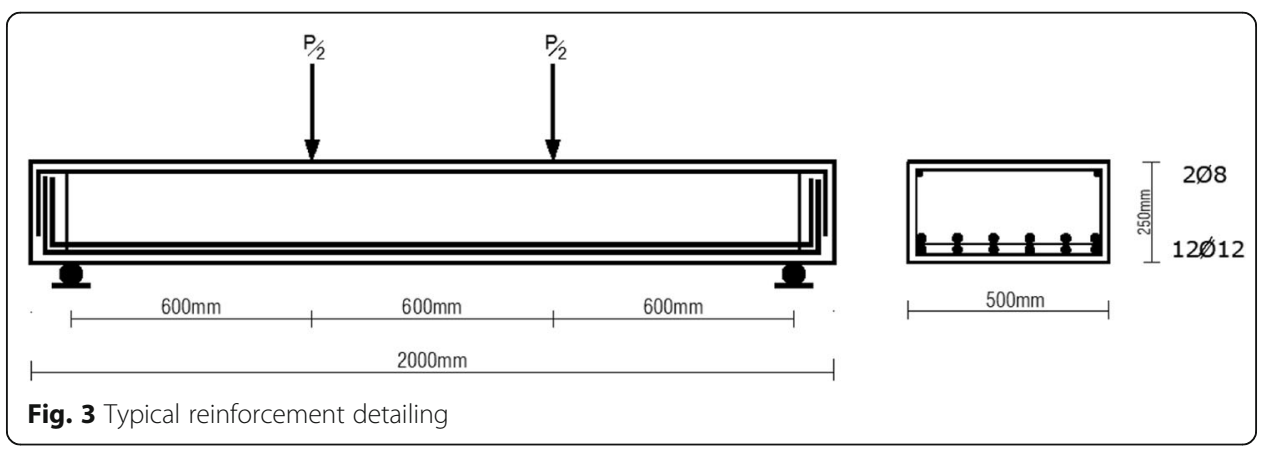




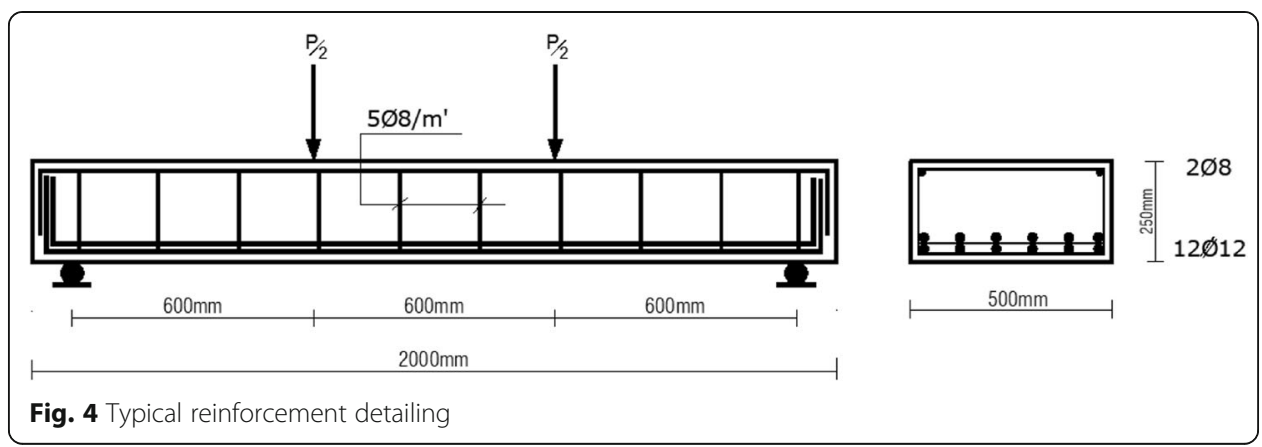

accordance with maximum aggregate size considerations and surface appearance reinforcement.

\section{Specimens details}

Dimensions of all reinforced shallow wide reinforced concrete beams were $500 \mathrm{~mm}$ width, $250 \mathrm{~mm}$ depth, and $2000 \mathrm{~mm}$ length span with a clear span of $1800 \mathrm{~mm}$. they were designed to fail in shear stresses of specimens. Experimental program test was carried out on five concrete beams (HB1, HB2, HB3, HB4, and HB5) that have $0 \%, 0.5 \%, 1.0 \%$, and $1.5 \%$ short glass fiber, respectively, and typical specimens were detailed and showed in Figs. 3 and 4. For shallow wide concrete beam specimens without/with web stirrup reinforcement, respectively, HB1 represent shallow wide reinforced concrete beam without web reinforcement. Reinforced concrete beam specimen (HB2) without short glass fiber reinforced polymer content represent shallow wide reinforced concrete beam with a minimum requirement of steel stirrups web reinforcement without short glass fiber reinforced polymer. HB3, HB4, and HB5 represents shallow wide reinforced concrete beams with a minimum required of steel stirrups web reinforcement, which the stirrups should be arranged so that the distance between stirrups should not exceed $200 \mathrm{~mm}$ along the beam specimen length according to Egyptian Code Practice (203-2018) [5]. It has to be mentioned that the role of the stirrups in such a case is to keep the longitudinal bars in place and to confine concrete in the cross-section. In addition, short glass fiber reinforced polymer with percentages by volume $0.50 \%, 1.00 \%$, and $1.50 \%$, respectively, as detailed in Table 5. Experimental tested specimen beams were divided into 3 groups regarding parameters study as detailed in Table 6.

Table 5 Specimens reinforcement details

\begin{tabular}{lllll}
\hline Beam ID & Bottom longitudinal RFT & Top longitudinal RFT & $\begin{array}{l}\text { Web Stirrups* } \\
\text { (Steel bars) }\end{array}$ & $\begin{array}{l}\text { Short glass fiber } \\
\text { reinforced polymer }\end{array}$ \\
\hline HB1 & $12 \varphi 12$ & $2 \varphi 8$ & --- & --- \\
HB2 & $12 \varphi 12$ & $2 \varphi 8$ & $5 \varphi 8 / \mathrm{m}^{\prime}$ & -- \\
HB3 & $12 \varphi 12$ & $2 \varphi 8$ & $5 \varphi 8 / \mathrm{m}^{\prime}$ & $0.50 \%$ \\
HB4 & $12 \varphi 12$ & $2 \varphi 8$ & $5 \varphi 8 / \mathrm{m}^{\prime}$ & $1.00 \%$ \\
HB5 & $12 \varphi 12$ & $2 \varphi 8$ & $5 \varphi 8 / \mathrm{m}^{\prime}$ & $1.50 \%$ \\
\hline
\end{tabular}


Table 6 Experimental work details

\begin{tabular}{|c|c|c|c|}
\hline Group No. & Parameter effect & Behavior study & Specimen ID \\
\hline G1 & $\begin{array}{l}\text { Effect of steel reinforcement due to } \\
\text { shear strength }\end{array}$ & $\begin{array}{l}\text { Contribution of web stirrup reinforcement } \\
\text { against shear strength }\end{array}$ & $\begin{array}{l}\mathrm{HB} 1 \\
\mathrm{HB} 2\end{array}$ \\
\hline \multirow[t]{3}{*}{ G2 } & $\begin{array}{l}\text { Effect of short glass fiber percentage } \\
\text { with a minimum web shear stirrup } \\
\text { reinforcement due to shear strength }\end{array}$ & $\begin{array}{l}\mathrm{G}(2-1) \\
\text { Contribution of } 0.5 \% \text { of short glass fiber } \\
\text { reinforcement against shear strength }\end{array}$ & $\begin{array}{l}\text { HB2 } \\
\text { HB3 }\end{array}$ \\
\hline & & $\begin{array}{l}\mathrm{G}(2-2) \\
\text { Contribution of } 1.00 \% \text { of short glass fiber } \\
\text { reinforcement against shear strength }\end{array}$ & $\begin{array}{l}\mathrm{HB} 2 \\
\mathrm{HB} 4\end{array}$ \\
\hline & & $\begin{array}{l}\mathrm{G}(2-3) \\
\text { Contribution of } 1.5 \% \text { of short glass fiber } \\
\text { reinforcement against shear strength }\end{array}$ & $\begin{array}{l}\text { HB2 } \\
\text { HB5 }\end{array}$ \\
\hline \multirow[t]{2}{*}{ G3 } & $\begin{array}{l}\text { Effect of short glass fiber percentage } \\
\text { due to shear strength }\end{array}$ & $\begin{array}{l}G(3-1) \\
\text { Effect of short glass fiber percentage } \\
\text { without minimum web steel stirrup } \\
\text { reinforcement }\end{array}$ & $\begin{array}{l}\text { HB1 } \\
\text { HB3 } \\
\text { HB4 } \\
\text { HB5 }\end{array}$ \\
\hline & & $\begin{array}{l}\mathrm{G}(3-2) \\
\text { Effect of short glass fiber percentage } \\
\text { with minimum web steel stirrup } \\
\text { reinforcement }\end{array}$ & $\begin{array}{l}\text { HB2 } \\
\text { HB3 } \\
\text { HB4 } \\
\text { HB5 }\end{array}$ \\
\hline
\end{tabular}

\section{Test setup and instrumentation}

The $1800 \mathrm{~mm}$ clear span shallow wide concrete beams were simply supported over two rigid supports, as shown in Fig. 5. Specimens were tested under load control with increments of $10 \mathrm{kN}$ up to failure using a hydraulic jack attached to a load cell with a capacity of $1000 \mathrm{kN}$. The load was applied vertically at the center of the rigid steel beam which transmitted the load equally on two bearings resting on the top of the beam and spaced at $600 \mathrm{~mm}$.

Deflections were measured using linear variable transducers (LVDT); one LVDT was used to determine deflections at mid-span of the beam, while two LVDTs were attached to the beams' bottom near the supports to check for any support movement while recording initial readings. Strain in the reinforcement was measured using strain gauges attached directly to

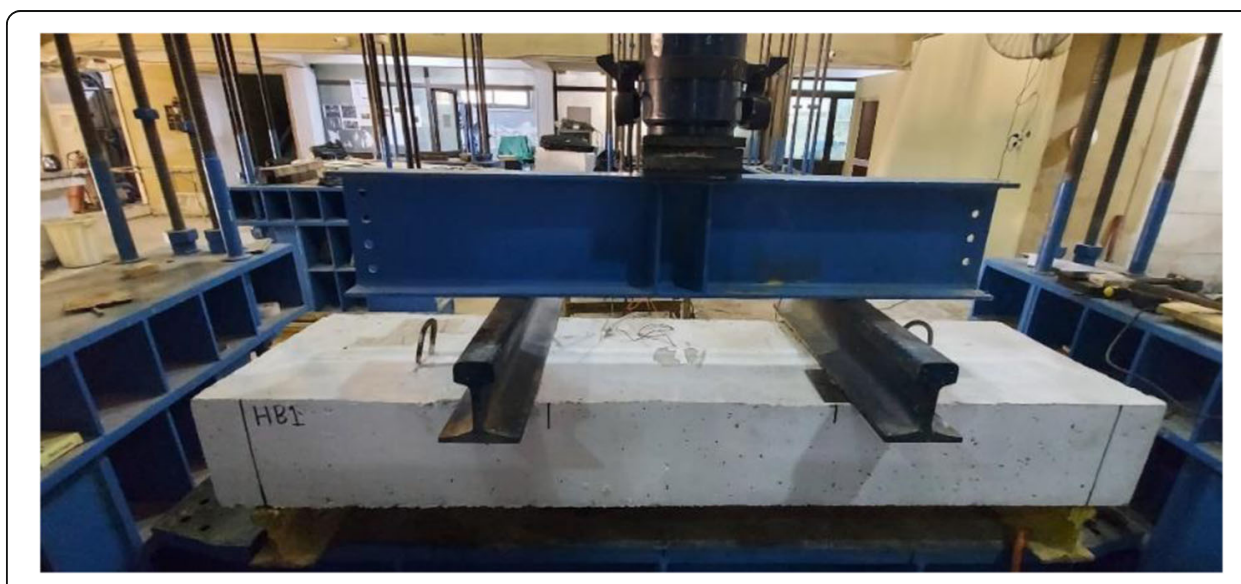

Fig. 5 Test setup 


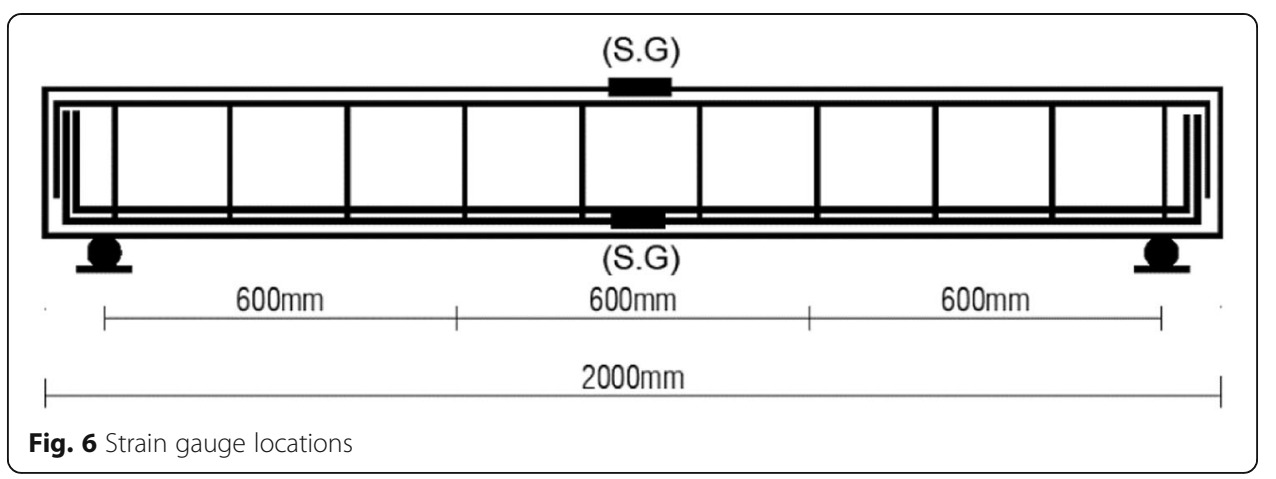

the rebars as shown in Fig. 6 . The measured data were recorded by a data logger connected to the computer system program "lab view" software.

\section{Results and discussions}

\section{Crack pattern and failure mode}

All shallow wide concrete beam specimens were subjected to a 4-point loading system up to failure, and the cracks were observed and marked continuously during the loading time. The cracking patterns for all tested shallow wide beams specimens were investigated and are shown in Figs. 7, 8, 9, 10, and 11. All tested specimens were designed to fail in shear. This presumption was investigated for all tested specimens. For specimen beams reinforcement HB1 (without steel web reinforcement and short glass fiber), the first observed crack $\left(\boldsymbol{P}_{\text {cr }}\right)$ was a diagonal in the shear span of reinforced concrete beam specimen and propagated diagonally towards the top compression flange and during subsequent loading stages additional vertical micro flexural cracks appeared, for remaining specimens beam reinforced, HB2 (with steel web reinforcement), HB3 (with steel web reinforcement and 0.5\%of glass fiber segments), HB4 (with steel web reinforcement and 1\% of glass fiber segments), and HB5(with steel web reinforcement and $1.5 \%$ of glass fiber segments). Although the major crack propagated from the support to the point of loading as the load increased up to the beams' failure a brittle failure mode for beam specimen HB1 compared to beam specimens HB2, HB3, HB4, and HB5 were observed. And increase in the number of crack patterns with decreasing in crack width at failure load for beam specimens HB2, HB3, HB4, and HB5 compared with beam specimen HB1 was observed also. Finally, it is found that the spread of external cracks increases by increasing the percentage of short glass fiber in concrete from $0.5 \%$ up to $1.5 \%$ and using web shear stirrup reinforcement also. the first batch crack of cracks was vertical flexural cracks occurring near mid-span after

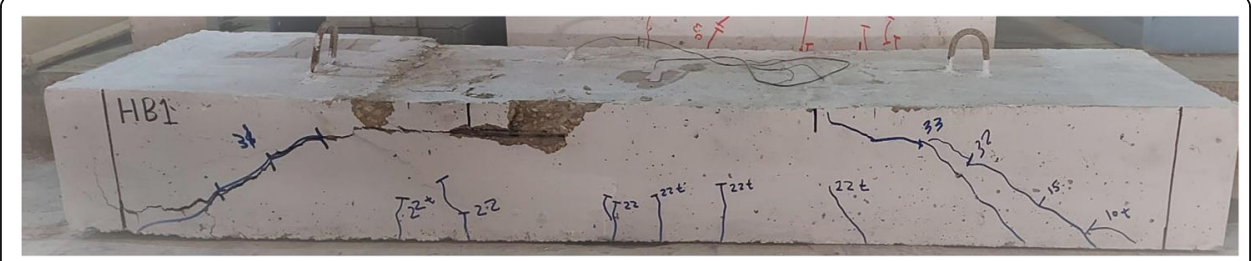

Fig. 7 Crack patterns at failure for shallow wide tested beam (HB1) 


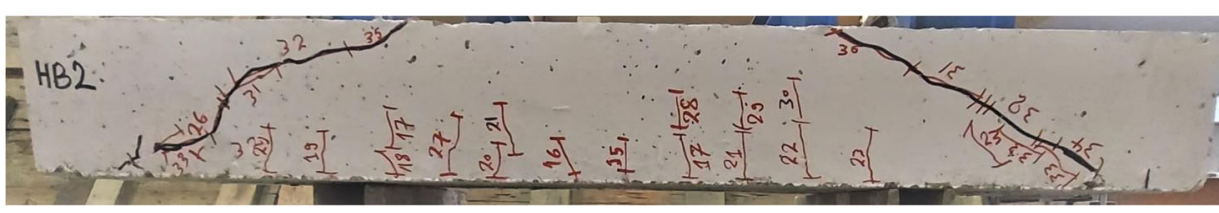

Fig. 8 Crack patterns at failure for shallow wide tested beam (HB2)

that, additional diagonal shear cracks appeared and propagated towards the top compression flange during increasing of loading test through a substantial depth of the specimen section. The first cracking load $\left(\boldsymbol{P}_{\mathbf{c r}}\right)$, yield, and maximum failure measured load as well as their relative vertical deflections for all tested specimens beam were monitored and listed in Table 7.

The first diagonal cracking load $\left(\boldsymbol{P}_{\text {diagonal }}\right)$ and ratio by failure load $\left(\boldsymbol{P}_{\text {failure }}\right)$ were listed in Table 7. The cracking loads ranged from 25 to $29 \%$ of the failure loads, while the diagonal cracks appeared at loads ranging from 10 to $31 \%$ of the maximum failure loads. By comparing between shallow wide beam without web shear stirrup reinforcement and shallow wide beam with web shear stirrup reinforcement, it was found that the web shear stirrup reinforcement slightly affects on the delay of the cracking load. However, the diagonal cracking loads were delayed up to $49 \%$ of HB2 by compared with HB1. While the shallow wide beams specimens reinforced with web shear stirrups and glass fiber segments HB3, HB4, and HB5, the cracking load was increased by $20 \%, 30 \%$, and $30 \%$, respectively, compared with shallow wide beam HB1 without any web shear stirrups and glass fiber reinforcement. And the diagonal cracking was delayed by $43.85 \%, 50.80 \%$, and $76.00 \%$ for specimens HB3, HB4, and HB5, respectively, compared with HB1. However, glass fiber segments enhanced the cracking pattern of a shallow wide beam and delayed the diagonal cracking shear due to increase in the tensile resistance of concrete when using a short glass fiber in the concrete mix as shown in Table 8. It is clear that the increase in the fiber content led to a significant increase in the deflections at the same load, where observed that the increasing in the deflection at cracking and failure loads for concrete beam specimen HB5 increased by $48 \%$ and $17 \%$, respectively, compared with beam specimen HB4 and this may attribute to the short glass fibers led to poor bonding between concrete components such as coarse aggregate particles, and between fine aggregate particles.

The types of the first cracking, flexural cracking load, shear cracking load, and modes of failure were listed in Table 9. Increasing in a number of vertical flexural cracks for specimens HB3, HB4, and HB5, compared with specimens HB1 and HB2, this is indicated that the glass fiber segments, which distributed randomly in shallow wide beam specimens during concrete pouring, can be enhanced and increase the shear strength

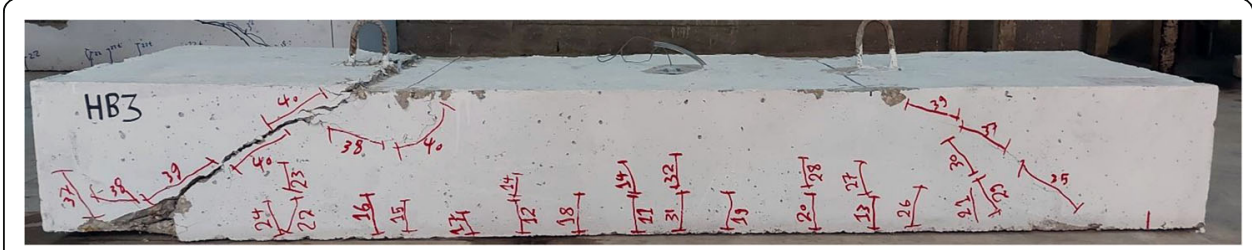

Fig. 9 Crack patterns at failure for shallow wide tested beam (HB3) 


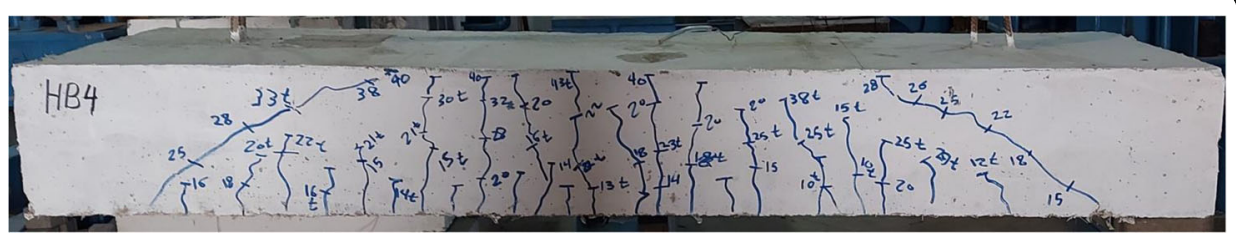

Fig. 10 Crack patterns at failure for shallow wide tested beam (HB4)

of the shallow wide beams and can be changed the modes of shallow wide beam reinforced beams from clearly shear failure as an occurred in specimen HB1 to flexural shear failure as an occurred in specimen HB3, HB4, and HB5 as shown in figures before. And web shear stirrup reinforcement can be also enhanced and increasing in shear strength of shallow wide beam especially when used glass fiber segments as an additional web shear reinforcement in a shallow wide beam.

\section{Strain in reinforcement and concrete}

Figure 12 plots the measured mid-span strain of tensile steel bars and the top surface of concrete versus the applied load for tested beams specimen. Strain characteristics in longitudinal reinforcement and concrete specimens are listed in Table 10. The strains of the main steel bars are larger than in tested specimen without web shear stirrup reinforcement (HB1) compared to the tested specimen with web shear stirrup reinforcement (HB2), tested specimens with web shear stirrup reinforcement and glass fiber segments HB3, HB4, and HB5 by $10.48 \%, 21.68 \%, 29.75 \%$, and $44.70 \%$, respectively. Decreasing in concrete strain for shallow wide beams reinforced by stirrups and glass fiber HB3, HB4, and HB5 compared to shallow wide beam without web shear stirrup reinforcement (HB1) by $27.75 \%, 30.76 \%$, and $12.04 \%$, respectively. The reduction in the steel strain of longitudinal bars and concrete strain of the shallow wide beam specimens which consists of web shear stirrup reinforcement and glass fiber segments can be indicated that the use of web shear stirrup reinforcement and glass fiber segments can be contributed and increasing of its shear strength due to enhancement in ductility of beams [11].

\section{Load deflection behavior}

The load deflection curves measured at the mid-span of beams specimens were shown in Fig. 13. In general, using web shear stirrup reinforcement increased the maximum failure load by $5.62 \%$ as well as the use of glass fiber segments' random distribution as concrete reinforcement with web shear stirrup reinforcement increases the maximum failure load up to $11.62 \%$.

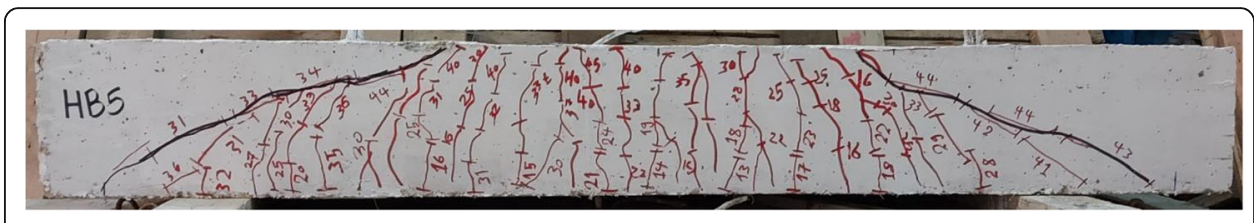

Fig. 11 Crack patterns at failure for shallow wide tested beam (HB5) 
Table 7 Experimental results of tested beams

\begin{tabular}{llllllllll}
\hline Specimen & $\begin{array}{l}\boldsymbol{P}_{\text {diagonal }} \\
(\mathbf{K N})\end{array}$ & $\begin{array}{l}\boldsymbol{P}_{\boldsymbol{c r}} \\
(\mathrm{KN})\end{array}$ & $\begin{array}{l}\boldsymbol{\Delta}_{\boldsymbol{c r}} \\
(\mathbf{m m})\end{array}$ & $\begin{array}{l}\boldsymbol{P}_{\boldsymbol{y}} \\
(\mathbf{K N})\end{array}$ & $\begin{array}{l}\boldsymbol{\Delta}_{\boldsymbol{y}} \\
(\mathbf{m m})\end{array}$ & $\begin{array}{l}\boldsymbol{P}_{\text {failure }} \\
(\mathbf{K N})\end{array}$ & $\begin{array}{l}\boldsymbol{\Delta}_{\boldsymbol{u}} \\
(\mathbf{m m})\end{array}$ & $\frac{\boldsymbol{P}_{\text {crack }}}{\boldsymbol{P}_{\text {failure }}}$ & $\frac{\boldsymbol{P}_{\text {diagonal }}}{\boldsymbol{P}_{\text {failure }}}$ \\
\hline $\mathrm{HB1}$ & 100 & 100 & 8.40 & 338.5 & 13.17 & 400 & 19.56 & 0.25 & 0.25 \\
$\mathrm{HB} 2$ & 210 & 110 & 3.57 & 324.0 & 8.88 & 422.5 & 13.50 & 0.26 & 0.49 \\
$\mathrm{HB3}$ & 250 & 120 & 2.90 & 317.5 & 10.80 & 438 & 17.50 & 0.27 & 0.57 \\
HB4 & 280 & 130 & 3.43 & 270 & 10.20 & 446.5 & 17.53 & 0.29 & 0.62 \\
HB5 & 310 & 130 & 6.62 & 270 & 12.30 & 445.5 & 21.65 & 0.29 & 0.69 \\
\hline
\end{tabular}

As shown in Table 11, a reduction in a failure load at increasing the level of short glass fiber percentage over $1 \%$ was observed, and this may be attributed to poor bonding between concrete particles materials. And the traditional stirrup reinforcement with glass fibers as HB3, HB4, and HB5 increased the failure load by about 9.5\%, 11.62\%, and $11.37 \%$, respectively, compared to control beam HB1 without web shear stirrup reinforcement. So, from this result, it can be concluded that the use of web shear stirrup reinforcement in shallow wide reinforced concrete beam increasing in failure load capacity due to web stirrups significantly increases the shear resistance of the shallow wide reinforced concrete beam. In addition, the use of glass fiber as segments in the shallow wide beam can increase and enhance the strengthening of shallow wide beam against shear stresses.

Reduction in mid-span deflection HB2 uses web shear stirrup reinforcement by $30.98 \%$ compared with control beam HB1, although increasing in the maximum load capacity in HB2. It can be observed also that the use of glass fiber segments distributed randomly along shallow wide beam can decrease the deflection up to $10.50 \%$ although increasing the maximum load capacity compared with control beam specimen HB1.

Increasing in short glass fiber percentage of reinforced concrete shallow wide beams up to $1.5 \%$ leads to increasing in deflection by $10.68 \%$ compared with HB1, this is may be referring to increasing in maximum load failure capacity andlor increasing in glass fiber segments ratio leads to make a weakness of concrete.

Increasing in the deflection of $\mathrm{HB} 1$ compared with all remaining reinforced concrete beam specimens HB2, HB3, HB4, and HB5 at the same load level can be observed as shown in Fig. 13, referring to the use of short glass fiber in concrete beams which have a high tensile resistance against cracks in the tension zone of beam regarding to its capability to tensile strength as previously shown in Table 8 .

Table 8 The difference between compressive strength and tensile splitting strength due to short glass fiber in concrete

\begin{tabular}{lllll}
\hline Concrete type & Sample (ID) & $\begin{array}{l}\text { Average } \\
\boldsymbol{F}_{\mathrm{ct}}\left(\mathbf{N} / \mathbf{m m}^{2}\right)\end{array}$ & $\begin{array}{l}\text { Average } \\
\boldsymbol{F}_{\mathrm{cu}}\left(\mathbf{N} / \mathbf{m m}^{2}\right)\end{array}$ & $\begin{array}{l}\text { Concrete } \\
\text { (Tensile/compression) } \\
\text { ratio \% }\end{array}$ \\
\hline Concrete without GFRP & $\mathrm{G} 1$ & 1.89 & 25.50 & 7.41 \\
Concrete with (0.50\%) GFRP & $\mathrm{G} 2$ & 4.08 & 26.00 & 16.32 \\
Concrete with (1.0\%) GFRP & $\mathrm{G} 3$ & 4.58 & 25.70 & 17.82 \\
Concrete with (1.50\%) GFRP & $\mathrm{G} 4$ & 4.30 & 26.70 & 16.10 \\
\hline
\end{tabular}


Table 9 Cracking properties and modes of failure

\begin{tabular}{lllll}
\hline Specimens & Types of the first crack & $\begin{array}{l}\text { Flexural cracking load } \\
\text { (KN) }\end{array}$ & $\begin{array}{l}\text { Shear cracking load } \\
\text { (KN) }\end{array}$ & Modes of failure \\
\hline HB1 & Diagonal shear crack & 210 & 100 & Brittle shear failure \\
HB2 & Vertical flexure crack & 110 & 210 & Shear failure \\
HB3 & Vertical flexure crack & 120 & 250 & Flexural shear failure \\
HB4 & Vertical flexure crack & 130 & 280 & Flexural shear failure \\
HB5 & Vertical flexure crack & 130 & 310 & Flexural shear failure \\
\hline
\end{tabular}

By increasing in glass fiber segments percentage in shallow wide beam web shear stirrup reinforcement by $0.5 \%, 1 \%$, and $1.5 \%$, it can be seen that the deflection at yield was increased with $21.62 \%, 14.86 \%$, and $38.51 \%$ compared with HB2. Although the decreasing of yielding load, this is attributed to the glass fiber segments' random distribution in the shallow wide beam can be contributed to increase the shear strength of concrete. And although the increasing of the maximum loading capacity of specimens HB3, HB4 the decreasing in deflection at ultimate load compared with HB1 can be observed also.

\section{Ductility and stiffness}

Ductility refers to a material's ability to withstand permanent deformation under a tensile load without rupture. In this study, the ductility of all tested specimens was represented by calculating the ratio of maximum displacement to yield displacement, both measured at mid-span [9]. Figure 14 shows that the ductility of all tested beam specimens.

it can be observed that the shallow wide beam specimens HB1 and HB2 deflections values along beam span between yielding and ultimate loads were closely nearby. And

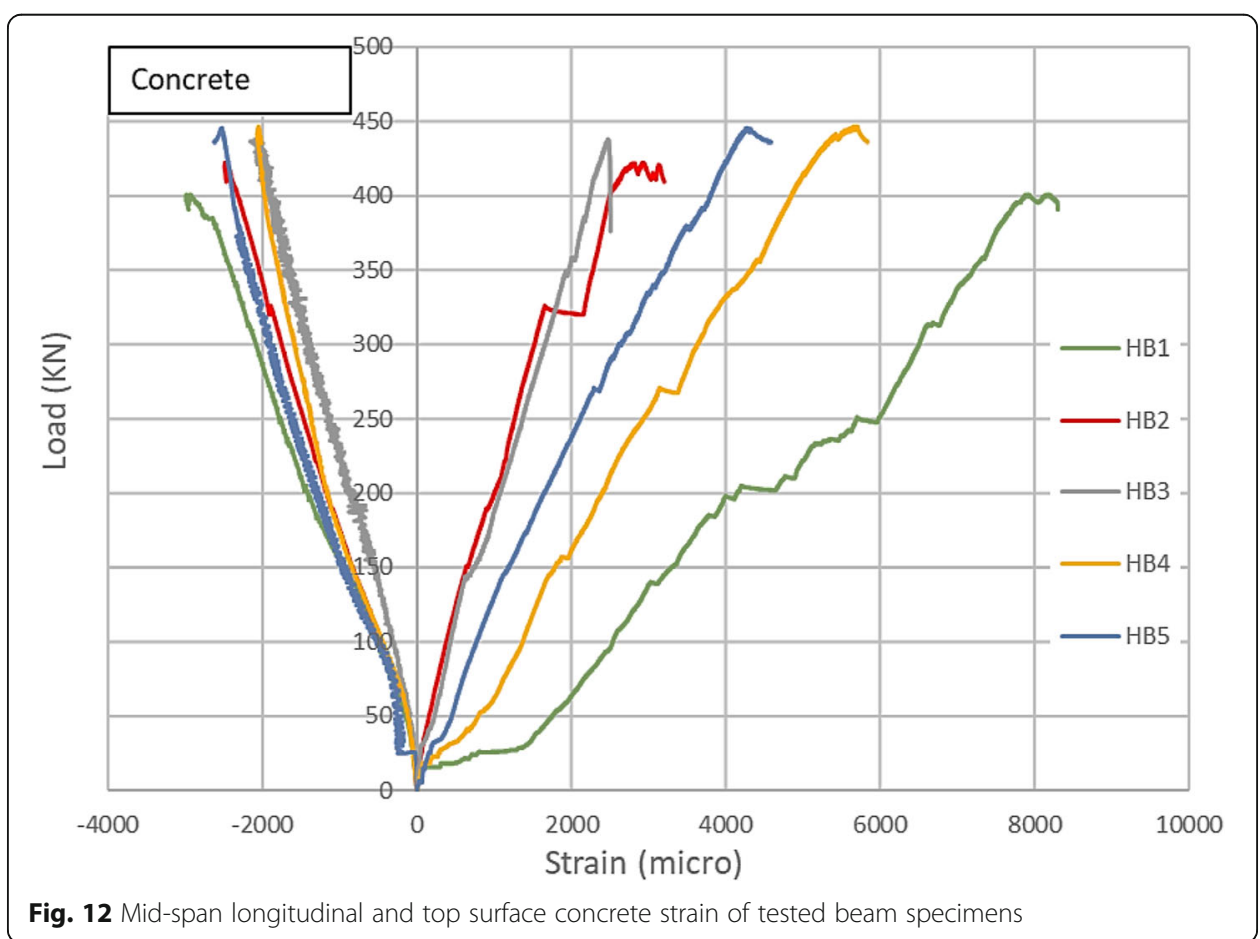


Table 10 Strain characteristics in longitudinal reinforcement and concrete of shallow wide beam specimens

\begin{tabular}{|c|c|c|c|c|}
\hline \multirow{2}{*}{$\begin{array}{l}\text { Beam } \\
\text { specimen }\end{array}$} & \multicolumn{2}{|c|}{ Longitudinal reinforcement } & \multicolumn{2}{|c|}{ Concrete compression } \\
\hline & $\begin{array}{l}\varepsilon_{\text {us }} \\
\times 10^{-3}\end{array}$ & $\%$ diff. of $\varepsilon_{u}$ & $\begin{array}{l}\varepsilon_{u c} \\
\times 10^{-3}\end{array}$ & $\%$ diff. of $\varepsilon_{u}$ \\
\hline HB1 & 8.30 & ----- & 2.99 & ---- \\
\hline HB2 & 7.43 & 10.48 & 2.50 & 16.38 \\
\hline HB3 & 6.50 & 21.68 & 2.16 & 27.75 \\
\hline HB4 & 5.83 & 29.75 & 2.07 & 30.76 \\
\hline HB5 & 4.59 & 44.70 & 2.63 & 12.04 \\
\hline
\end{tabular}

increasing in glass fiber percentages in specimens leads to increasing in the difference values of deflections between yielding and ultimate load as shown in the figures below. This is attributed to the use of glass fiber in shallow wide reinforced concrete beams increasing of specimen ductility and enhanced beam behavior against shear stresses.

Initial and post cracking stiffness of the tested beam were calculated based on the slope of the load deflection curve before and after crack, respectively. And Fig. 15 shows that the initial and post cracking stiffness of tested shallow wide beam specimens.

As shown in Figs. 14 and 15, increasing in glass fiber segments randomly distributed along shallow wide beam span leads to increasing in beam ductility up to $19 \%$ and can be observed that also; the using of web shear stirrup reinforcement leads to increasing in ductility by $2.7 \%$. this is attributed to the using of glass fiber segments in shallow wide beam which lead to increasing in post cracking stiffness up to $54.35 \%$ and delayed the first cracking to occur.

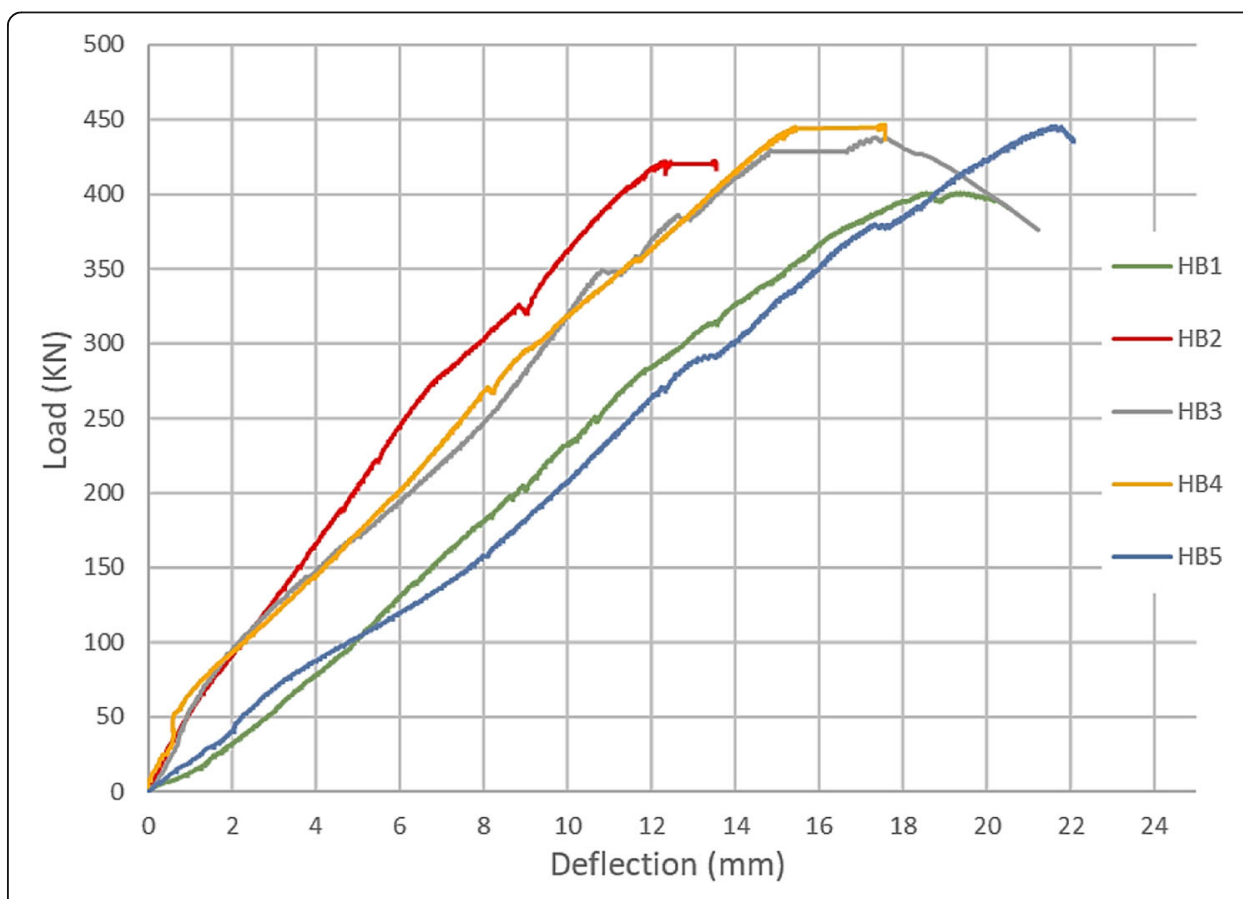

Fig. 13 Load deflection at mid-span of tested beam specimens HB1, HB2, HB3, HB4, and HB5 
Table 11 Comparison between the strength characteristics of specimens

\begin{tabular}{llllll}
\hline Specimen & \multicolumn{2}{l}{ Failure load } & & \multicolumn{2}{c}{ Deflection at failure load } \\
\cline { 2 - 3 } & $\boldsymbol{P}_{\text {failure }}(\mathrm{KN})$ & \%Diff. & & $\boldsymbol{\Delta}_{\boldsymbol{u}}(\mathbf{m m})$ & \%Diff. \\
\hline HB1 & 400 & ---- & & 19.56 & ---- \\
HB2 & 422.5 & $5.62 \%$ & & 13.50 & $-30.98 \%$ \\
HB3 & 438.0 & $9.50 \%$ & & 17.5 & $-10.5 \%$ \\
HB4 & 446.5 & $11.62 \%$ & & 17.53 & $-10.37 \%$ \\
HB5 & 445.5 & $11.37 \%$ & & 21.65 & $+10.68 \%$ \\
\hline
\end{tabular}

Using glass fiber segments effecting in the shallow wide beam behavior during failure where the first cracks appeared randomly within the middle third of the span (zone of the maximum moment) before shearing crack appeared for specimen HB3(containing $0.5 \%$ of glass fiber segments), HB4 (containing $1 \%$ glass fiber), and HB5 (containing $1.5 \%$ glass fiber), while the first crack was appeared for HB1 (without web shear stirrup reinforcement and glass fiber segments) and HB2 (with web shear stirrup reinforcement and without glass fiber segments) was diagonal shear cracking. The different behavior for specimens (HB3, HB4, and HB5) about specimens (HB1) and (HB2) due to using of glass fibers segments in the beam.

\section{Conclusions}

The following conclusions can be drawn from the analysis and discussion of the test results obtained during this investigation:

1- Using web shear stirrup reinforcement in shallow wide beam cause an increase in the maximum failure load up to $5.62 \%$ and delayed the occurring of the diagonal cracking up to $52 \%$.

2- Optimum short glass fiber ratio using in shallow wide beam according to present investigation is beyond $1.0 \%$.

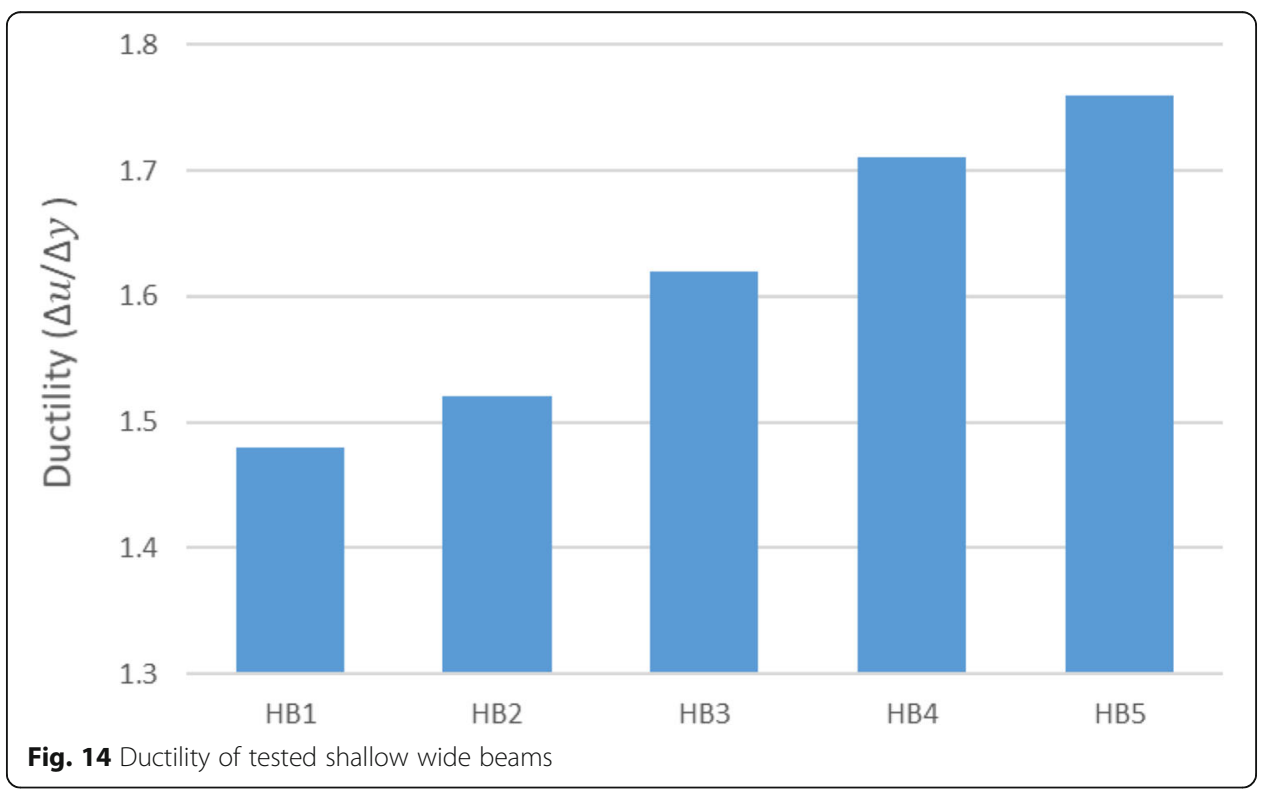




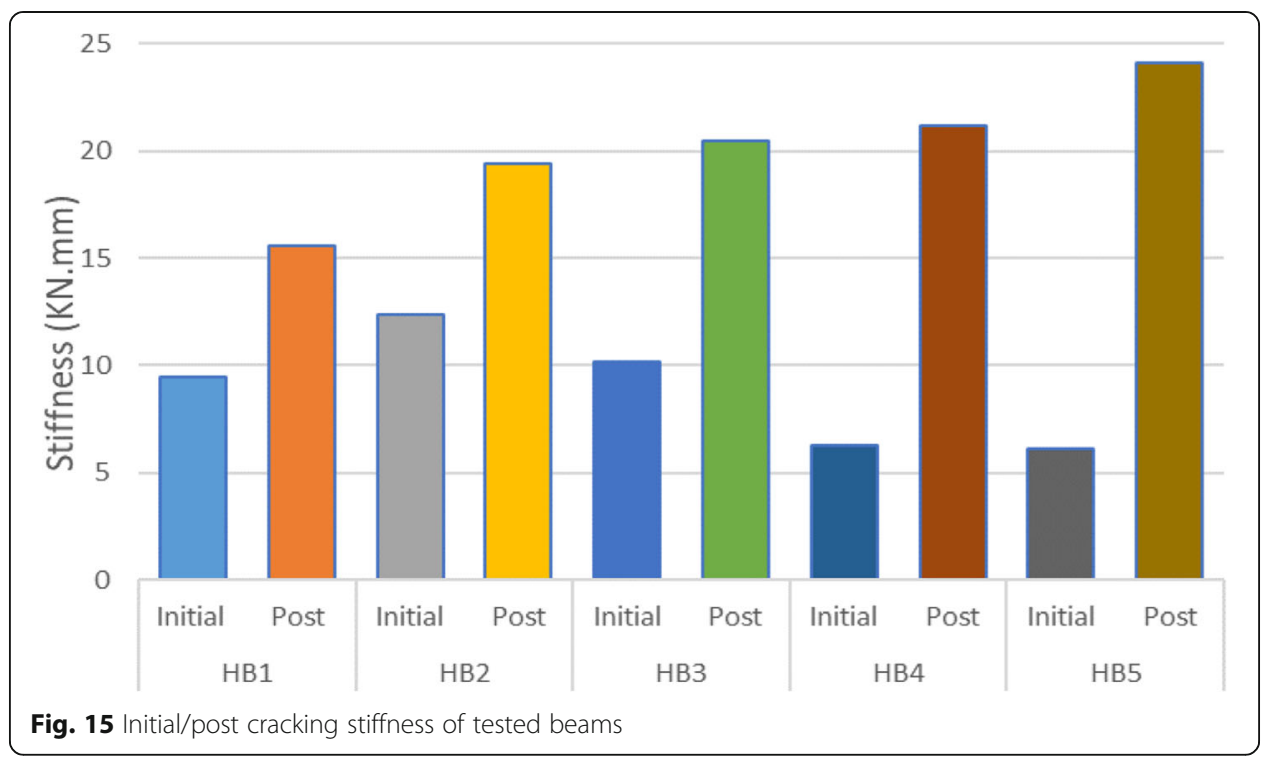

3- Using an optimum ratio of short glass fiber segments randomly distributed with web shear stirrup reinforcement in shallow wide beam cause an increase in the maximum failure load up to $5.12 \%$ and delayed the diagonal cracking up to $67.74 \%$.

4- The ductility of the shallow wide beam has a significant enhancement by using stirrups up to $2.70 \%$ and more enhancement can be achieved by using glass fiber segment up to $18.91 \%$ due to the increase in ductility.

5- Using web shear stirrup reinforcement led to a decrease in the main steel strain up to $10.48 \%$.

6- Glass fiber contributes increasing in the ductility due to increasing in post cracking.

7- Using glass fiber segments in shallow wide beam leads to improving in the performance of the beams in cracking, stiffness, and ultimate capacity.

8- Increasing in numbers of cracks, post cracking, ductility, and maximum failure loads due to the using of optimum ratio percentage of short glass fiber percentage in shallow wide reinforced concrete beam.

9- Increasing in percentage ratio of short glass fiber in shallow wide concrete beams led to increase in the tensile strength of concrete up to $17.82 \%$ compared with concrete without short glass fiber.

\section{Abbreviations}

GFRP: Glass fiber reinforced polymer; $F_{\mathrm{ct}}$ : Concrete splitting tensile strength; $F_{\mathrm{cu}}$ : Concrete compressive strength; $\varepsilon_{u c}$ : Concrete compression strain; $\varepsilon_{\text {us: }}$ Longitudinal reinforcement strain

\section{Acknowledgements}

Not applicable

\section{Author's contributions}

Corresponding author MSM is a post Ph.D researcher and did the experiment and wrote the manuscript. And I read and approved the final manuscript.

Funding

Own funding by author 
Availability of data and materials

The datasets collected and/or analyzed during the current study are available from the corresponding author on request. The corresponding author had full access to all the data in the study and takes responsibility for the integrity of the data and the accuracy of the data analysis.

\section{Declarations}

\section{Competing interests}

The author declares that he has no known competing financial interests or personal relationships that could have appeared to influence the work reported in this paper.

Received: 11 September 2021 Accepted: 27 November 2021

Published online: 13 December 2021

\section{References}

1. de Abreu Júnior L, Freire RTS, Oliveira PR, Chris-Toforo AL, Garcia CT, del Pino GG, Panzera TH (2020) Hybrid Short Glass Fibre Composites Reinforced with Silica Micro-particles. J Polym Sci Eng 3:1191-202

2. Tilekar P, Chandra M, Gowda K (2017) "Experimental Study on Strengthening of RC Beams by Using GFRP Wrapping", Conference Paper, ISBN: 978-93-5267-355-1

3. Sathishkumar TP, Satheeshkumar S, Naveen J (2014) Glass Fiber-Reinforced Polymer Composites. Journal of Reinforced Plastics and Composites 33(13):1258-1275

4. Morsy NS, Sherif AG, Shoeib AE, Agamy MH (2018) "Experimental Study of Enhancing the Shear Strength of Hidden/ Shallow Beams by Using Shear Reinforcement", Proceedings of the 3rd World Congress on Civil, Structural, and Environmental Engineering (CSEE'18), Budapest, Hungary, Paper No. ICSENM 116. https://doi.org/10.11159/icsenm18.116

5. Egyptian code of practice for design and construction of reinforced concrete structures (ECP203-2018). Fourth edition. Housing and Building Research Centre, Giza, Egypt

6. Lotfy E, Mohamadien HA (2014) Effect of Web Reinforcement on Shear Strength of Shallow Wide Beams. Int J Eng Tech Res 2(11):1484-98

7. Kim MS, Kang J, Lee YH (2018) Shear Strength of Concrete Wide Beams Shear Reinforced with GFRP Plates. Polym Polym Compos J 26(1):111-18

8. Kim MS, Kang J, Lee YH (2019) Improved Shear Strength Equation for Concrete Wide Beams. Appl Sci J 9(20):4513-28

9. Hanafy MM, Mohamed HM, Yehia NAB (2012) On the Contribution of Shear Reinforcement in Shear Strength of Shallow Wide Beams. Life Sci I 9(3):484-98

10. Khalil AE-H, Etman E, Atta A, Baraghith AT, Behiry RN (2018) Structural Performance For Wide-Shallow Beam In Shear (Comparative Study). journal engineering research (2):62-74

11. Ata E-k S, Soliman M, Osman A-M (2012) Efficiency of using discrete fibers on the shear behavior of R.C. beams. Ain Shams Eng J 3(3):209-217

\section{Publisher's Note}

Springer Nature remains neutral with regard to jurisdictional claims in published maps and institutional affiliations.

\section{Submit your manuscript to a SpringerOpen ${ }^{\circ}$ journal and benefit from:}

- Convenient online submission

- Rigorous peer review

- Open access: articles freely available online

High visibility within the field

- Retaining the copyright to your article 